\title{
CORRECTION
}

\section{Correction to: The prone transpsoas technique: preliminary radiographic results of a multicenter experience}

Luiz Pimenta ${ }^{1,2} \cdot$ Rodrigo Amaral $^{1} \cdot$ William Taylor $^{2} \cdot$ Antoine Tohmeh $^{3} \cdot$ Gabriel Pokorny $^{1}$ (I) $\cdot$ Raquel Rodrigues $^{1}$. Daniel Arnoni ${ }^{1} \cdot$ Thyago Guirelli $^{1} \cdot$ Matheus Batista $^{1}$

Published online: 19 June 2020

(c) Springer-Verlag GmbH Germany, part of Springer Nature 2020

Correction to: European Spine Journal

https://doi.org/10.1007/s00586-020-06471-y

Unfortunately, the third and fourth author names have been incorrectly published in the original publication. The complete correct names are given below.

The third author name should read as William Taylor.

The fourth author name should read as Antoine Tohmeh.

The original article has been updated.

Publisher's Note Springer Nature remains neutral with regard to jurisdictional claims in published maps and institutional affiliations.

The original article can be found online at https://doi.org/10.1007/ s00586-020-06471-y.

\footnotetext{
Gabriel Pokorny g.pokorny@patologiadacoluna.com.br

1 Instituto de Patologia da Coluna (IPC), São Paulo, SP, Brazil

2 University of California, UCSD, San Diego, CA, USA

3 Providence Holy Family Hospital, Spokane, WA, USA
} 